\title{
FUNCTIONS OF TEACHERS' TRANSLANGUAGING IN THE EFL CLASSROOM AT TWO JUNIOR HIGH SCHOOLS IN SINGARAJA
}

\author{
N. M. Sapitri ${ }^{1}$, I. G. Batan ${ }^{1}$, I. P. N. W. Myartawan ${ }^{1}$ \\ ${ }^{1}$ Universitas Pendidikan Ganesha \\ e-mail: sapitri_mia@yahoo.co.id, igd.batan@gmail.com,wmyartawan@gmail.com
}

\begin{abstract}
The use of the first language (L1) in the English as a foreign language (EFL) classroom is becoming an on-going debate. A newly growing view to the use of $\mathrm{L} 1$ in the foreign language (FL) classroom called translanguaging views that by utilizing the $\mathrm{L1}$ along with the TL in FL classroom is considered as functional practice of languages rather than an impediment in FL learning. Accordingly it is necessary to find out the functions of teachers' practice of translanguaging in the EFL classroom since this view has not been much researched yet. Related to this, the current study was intended to find out the functions of the EFL teachers' translanguaging and to find out the teachers' reasons for the use of translanguaging. This study followed qualitative descriptive interactive research design, and the subjects consisted of three English teachers at the $7^{\text {th }}$ grade classes at two junior high schools in Singaraja. The data were collected through observations and interviews and were analyzed descriptive qualitatively. The results of this study showed that there were 3 functions of translanguaging. The most frequent function was related to knowledge construction, followed by classroom management, and interpersonal relations. There were 9 reasons for the teachers' use of translanguaging, namely: to facilitate students' understanding, to provide L1 and TL comparison, to elicit students' responses, to attract students' attention, tomanage students, to promote discipline, to develop deeper personal relationship, to create secure classroom atmosphere, and to make the class more interesting. In sum, the use of translanguaging plays a number of functions in the EFL classroom but it should be considered also the 'optimal' use of it in EFL learning process because the overuse of L1 might bring negative impact.
\end{abstract}

Keywords: Translanguaging, knowledge construction, classroom management, interpersonal relations, EFL classroom

\section{INTRODUCTION}

The use of first language (L1) in the Englsih as a Second Language/ English as a Foreign Language (ESL/EFL) classroom becomes an on-going debate and research in recent. One perspective views the $L 1$ as an impediment in the target language ( $\mathrm{TL}$ ) learning while another perspective argues that $L 1$ as a purposive use of language. As Levine (2012) affirms that some follow a strict 'exclusive target language' pedagogy, while others still 'resort to' the use of the L1 for a variety of purposes. The advocators of the monolingual approach view that in the EFL/ESL classroom, L1 plays insignificant role and that it might dismiss students of valuable input in the $L 2$ and obstruct progress of learning the target language (Bouangeune, 2009; Ellis, 1985; Auerbach, 1993; as cited in Bhooth, Azman \& Ismail 2014). Another perspective views that $L 1$ plays a number of functions such as facilitating communication (Harbord, 1992), conveying meaning (Cook, 2001) facilitating studentteacher relationship (Harbord, 1992), and scaffolding and peer learning as cited in Bozorgian \& Fallahpour (2015).

Regarding to the contrasting views, a
newly growing approach named translanguaging tries to draw a new insight toward the use of L1 in TL classroom. This view considers that by utilizing L1 in FL classroom along with the $T L$ is considered as functional 
practice of languages. The definition of translanguaging is stated by García \& Wei (2014, as cited in Hassan \& Ahmed, 2015) as the bilingual or multilingual speakers' multicompetence who owned the ability to switch between languages while integrating them within a single linguistic system. In the classroom context particularly, García (2009) defines translanguaging as two languages are used in an integrated and coherent way to manage and facilitate the mental process of learning, whether by teachers or by students in the classroom. This integration of two languages is meant by the use of L1 and the TL. In addition, Martin (2005, as cited in Creese \& Blackledge, 2010) explains translanguaging as the use of local languages alongside the 'official language' of the lesson.

As the practice of the use languages, translanguaging as a new insight is different from code switching in term of the concept but they are similar in term of the pattern. Cahyani et al., (2016) clarifies that translanguaging differs from code-switching in that it is not merely switching in and out of two separate monolingual codes but combines two languages as a unity to achieve effective communication. However in term of the pattern, code switching may be seen as an instance of translanguaging, alongside other bilingual phenomena such as translation, borrowing, and additional processes, in a range of modalities, as in earlier treatments (Garcia, 2009, p. 45; Garcia, 2011, p. 147, as cited in MacSwan, 2017). Thus, translanguaging is considered as covering any multilingual phenomenon.

In the classroom context, the use of translanguaging by integrating the $\mathrm{L} 1$ and $\mathrm{TL}$ seems to be significant especially in EFL classroom. Harmer (2007) describes the EFL classroom as the situation when English is not learners' mother tongue because the learners normally have their own mother tongue or native language, and even have first and second language before studying English in the classroom. As Nayar (1997, as cited in Nambisan, 2014) notes that EFL refers to English instruction in schools which are located in nations or regions in which English is taught as a subject, but outside of the classroom it has no official or necessary use. By this situation combining the use of $\mathrm{L} 1$ in EFL classroom might support the mastery of the TL.

The advantages of the use of translanguaging by the teacher in the classroom are clearly identified by Baker (2001). He mentiones there are four potential advantages of the use of translanguaging in the classroom. Those are it may promote deeper and fuller understanding of the subject matter; it may help students develop skills in their weaker language; it can facilitate home-schooling cooperation; and the integration of both languages in the class so the learners then can develop learners' second language ability concurrently with content learning.

Besides bringing some advantages, translanguaging is also playing a number of functions. Ferguson (2003) modified by Cahyani, et al. (2016) classifies there are four functional categories of the practice of codes witching by the teacher in the classroom. The first three functions are from Ferguson (2003)'s classification and the last one emerges from Cahyani, et al.'s (2016) study. They are knowledge construction, classroom management, interpersonal relations, and personal and affective meanings.

The four functional classifications by Ferguson (2003) modified by Cahyani, et al., (2016) were used as the theoretical framework of this study. Firstly, knowledge construction as the function of translanguaging is basically to help pupils understand the subject matter of their lessons. For instance it is for pedagogical scaffolding of content lessons, conceptual reinforcement, annotation of key second language (L2) technical terms, and review of a topic (Cahyani, et al. (2016). Secondly, classroom management encompasses the use of translanguaging by the teacher to regulate the students' behaviour in their learning process. It includes negotiating task instructions, inviting pupil contributions, disciplining pupils, specifying a particular addressee, and so on (Ferguson, 2003). Thirdly, interpersonal relations mean that the use of translanguaging by the teacher in his/her relationship to his or her students. It consists of 
humanising the affective climate of the classroom and to negotiate different identities (Ferguson, 2003). The last one is the function of translanguaging that appears in Cahyani, et al.'s (2016) study named personal and affective meanings. Based on Cahyani, et al. (2016) personal and affective meanings cover the teacher's personal experiences, feelings, and sociocultural functions such as saving face.

As the phenomena found at two junior high schools in Singaraja, while the preliminary observations were conducted the teachers were found very spontaneously used translanguaging, a part used English as a target language, the other part used Indonesian language (L1) in order to maximize their effective communication in the classroom. However, as a new view in TL learning, the use of translanguaging in EFL classroom has not much been researched yet. There were only few studies conducted such as Cahyani, et al. (2016), Hassan \& Ahmed (2015), Lasagabaster (2013) and Bezzina (2016) that basically investigated the how and why translanguaging was used by the teacher. Thus, a study on the use of translanguaging in the classroom especially on the functions of translanguaging is significant to be conducted in order to enrich the literature of translanguaging.

Accordingly, there were two purposes of this study. They are (1) to describe the functions of teachers' Translanguaging in the EFL Classroom at Two Junior High Schools in Singaraja and (2) to describe teachers' reasons for the use of translanguaging in the EFL classroom at two junior high schools in Singaraja.

\section{METHODOLOGY}

This study was a qualitative descriptive study which followed Maxwell \& Loomis's (2002) interactive model. It was conducted at two junior high schools in Singaraja. The subjects of this study were three English teachers at the seventh grade classes. The objects of this study were the functions of teachers' translanguaging and the teachers' reasons for the use of translanguaging in the EFL classroom at two junior high schools in Singaraja. The data was obtained through classroom observation and interview method. The data in observation method were obtained by involving audio recorder equipment and observation checklist instrument while in the interview method were gained by involving audio recorder equipment and list of interview questions instrument. Then, the collected data were transcribed and analyzed qualitative descriptively. The data obtained through observations and interviews were analyzed qualitatively. However the data of the functions of the EFL teachers' translanguaging obtained through observation were also analyzed descriptively by presenting the most frequent function appearing. The data were analyzed by using Miles \& Huberman's (1984) flow model of analysis which included the process of data reduction, data display, and conclusion drawing or verification. The four functional categories mentioned by Ferguson (2003) modified by Cahyani, et al., (2016) were also used as the theoretical framework.

\section{RESULT AND DISCUSSION}

Table 1. The Frequency of Occurrence of Each Translanguaging Function

\begin{tabular}{|c|c|c|c|c|c|c|c|}
\hline \multirow[t]{2}{*}{ No. } & \multirow[t]{2}{*}{ Functions } & \multicolumn{3}{|c|}{ Number of Occurrence } & \multirow[t]{2}{*}{ Total } & \multirow[t]{2}{*}{ Mean } & \multirow[t]{2}{*}{$\%$} \\
\hline & & T1 & T2 & T2 & & & \\
\hline 1 & Knowledge Construction & 37 & 51 & 79 & 167 & 55.67 & 49.70 \\
\hline 2 & Classroom Management & 31 & 59 & 40 & 130 & 43.33 & 38.69 \\
\hline 3 & Interpersonal Relations & 6 & 11 & 22 & 39 & 19.00 & 11.61 \\
\hline \multirow[t]{2}{*}{4} & $\begin{array}{l}\text { Personal and Affective } \\
\text { Meanings }\end{array}$ & 0 & 0 & 0 & 0 & 0.00 & 0.00 \\
\hline & \multicolumn{4}{|c|}{ Total } & 336 & & 100 \\
\hline
\end{tabular}


The table 1 above indicated the functions of teachers' translanguaging appearing at two junior high schools in Singaraja. The function that mostly appeared at was about knowledge construction with the mean of occurrence of 55.67. The second most frequent function appearing was about classroom management with the mean of occurrence of 43.33. The least function occurred was about interpersonal relations with the mean of occurrence of 19.00 . While the function for personal and affective meanings were not found.

Knowledge construction was the most frequent functions appearing in the EFL classrooms at two junior high schools in Singaraja with the mean of occurrence of 55.67. It covered all aspects of transferring knowledge from the teacher to students including teachers' activities in mediating the students' learning for students' comprehension. In this study the function of teachers' translanguaging as constructing knowledge included to elicit students' response, to highlight important information, to explain new topic, to explain grammatical point, and to explain vocabulary.

The function of translanguaging for constructing knowledge was similar to the result of the research conducted by Cahyani, et al. (2016). In their study it was found that teachers' code-switching in constructing knowledge function was frequently used to support students to gain understanding of unfamiliar concepts, where the pedagogical focus was on the subject matter more than on language. In addition, Hassan \& Ahmed's (2015) study found that switching the teachers' language into students' L1 may promote a deeper and fuller understanding of the subject matter. As in this study the function of translanguaging to gain better understanding related to the subject matter was expressed in eliciting students' response, highlighting important information as well as explaining a new topic.

The second most frequent function of translanguaging which appeared in this study was about classroom management with the mean of occurrence of 43.33. This function was about regulating the students' behaviour in the classroom learning process which consisted of giving instruction, explaining task methodology, promoting discipline, inviting students' contribution, and gaining attention.

This result was relevant to the result of study conducted by Cahyani, et al. (2016). In their finding, it took place most frequently when teachers assigned tasks, signalled a shift of topic or activity, or disciplined students' behaviour. The function of translanguaging in this study particularly dealing with promoting discipline among students also echoed Lasagabaster's (2013) finding who mentioned that translanguaging was used to deal with disciplinary issues. More specific function of translanguaging in this study which was to explain task methodology also highlighted Bezzina's (2016) study which found that translanguaging used by the teacher in dealing with task management. There were some categories of the use of teachers' translanguaging related to classroom management function mentioned above which basically referred to the way the teachers regulate students' behaviour in order to create effective classroom situation.

The last classification of the functions of teacher's translanguaging found were interpersonal relations with the mean of occurrence of 19.00. Interpersonal relations meant that the use of translanguaging by the teacher in his/her relationship to his or her students. It consisted of building rapport, making a joke, giving praise and encouraging students.

This result was relevant to the result of the study conducted by Cahyani, et al. (2016). In their finding, it took place most frequently when teachers assigned tasks, signalled a shift of topic or activity, or disciplined students' behaviour. The function of translanguaging in this study particularly dealing with promoting discipline among students also echoed Lasagabaster's (2013) finding who mentioned that translanguaging was used to deal with disciplinary issues. More specific function of translanguaging in this study which was to explain task methodology also highlighted Bezzina's (2016) study which found that translanguaging used by the teacher in dealing with task management. There were some 
categories of the use of teachers' translanguaging related to classroom management function mentioned above which basically referred to the way the teachers regulate students' behaviour in order to create effective classroom situation.

The three functions of teachers' use of translanguaging appeared in the EFL classrooms at two junior high schools in Singaraja as already elaborated above were relevant to the theory of Ferguson (2003) about the functions of code switching (code switching is an important part of translanguaging) but different from theory of Ferguson (2003) which has been modified by Cahyani, et al. (2016) as the theoretical framework of this study. Based on Ferguson's (2003) categorization, there are three functions of teachers use of translanguaging in the classroom namely knowledge construction, classroom management and interpersonal relations. However Cahyani, et al.'s (2016) study found one more function which is called as personal and affective meanings. While this study shows the reduction of what have been found by Cahyani, et al. (2016) in which personal and affective meanings as the function of translanguaging was not found.

Related to the teachers' reasons for the use of translanguaging in the EFL classroom at two junior high schools in Singaraja, the result showed that there were nine main teachers' reasons which had been classified into three categorical reasons. They were to facilitate students' understanding, to provide $\mathrm{L} 1$ and TL comparison, and to elicit students' response categorized as knowledge construction; to attract students' attention, to be able to manage all students, and to promote discipline categorized as classroom management function; and to develop deeper personal relationship with the students, to create secure classroom atmosphere, and to make the class more interesting could be identified as interpersonal relations.

In the knowledge construction category, the first reason was about facilitating students' understanding. By the use of translanguaging as bilingual practice by utilizing the use of $\mathrm{L} 1$ in $\mathrm{FL}$ classroom, it was able to facilitate students' understanding. This reason was relevant to Harbord (1992, as cited in Adnan, et al., 2014) who mentions one reason of using $\mathrm{L} 1$ is facilitating the learning of $L 2$. This reason was also clearly stated by Baker (2001) who emphasizes that translanguaging may promote a deeper and fuller understanding of the subject matter. Different terms were used in the previous study such as to gain better comprehension and to help students understanding in Lasagabaster (2013); and ensuring comprehension and negotiating metalinguistic knowledge in Bezzina (2016).

The other reason related to knowledge construction was to provide $\mathrm{L} 1$ and $\mathrm{TL}$ comparison. The existence of L1 in FL classroom could give meaning to content that could not be conveyed through TL. This reason was relevant to Garcia (2007, as cited in Hidayati, 2012) who clearly explains that teachers need to overcome communication difficulties by expressing something in L1 which is difficult to be explained in L2. Besides that building the concept in students' mind about TL is easier to be understood in L1. In addition, Cook (2001, as cited in Adnan, et al., 2014) stresses this reason that $L 1$ is used to build up interlinked $L 1$ and L2 knowledge in the students' minds.

Eliciting students' response was also found as the reason of teachers's translanguaging as knowledge construction. Students mostly did not be active in the class because they did not understand what their teacher was saying. This reason was relevant to Atkinson's (1987) argument as cited in Mahmutoglu and Kicir (2013) who says one situation when L1 is used is to elicit language. Additionally, this reason supported Harbord's (1992) theory as cited in Adnan, et al. (2014) who argues L1 facilitates communication. This theory is relevant to the intention of eliciting students' response that is to make them able to communicate in the EFL classroom. This study also highlighted Lasagabaster's (2013) research that used different term that was to boost debate.

In the classroom management category, there were three teachers' reason found namely to attract students' attention, to be able to manage all students, and to promote 
discipline. These three reasons basically referred to manage students' behaviour in the classroom. These reasons emphasized what Garcia (2007, as cited in Hidayati, 2012) statement who says that teachers need to manage students' behaviour by utilizing students' L1.This reason is also conveyed by Cook (2001, as cited in Hidayati, 2012) in which teachers can use L1 for classroom organization purposes such as maintaining discipline. This reason also proved the Lasagabaster's (2013) finding toward teachers' perspective on the use of translanguaging stating that translanguaging was used to deal with disciplinary issues. In addition this reason also echoed Bezzina's (2016) finding mentioning one teachers' perspective on the use of translanguaging is dealing with rules/class functioning.

Related to interpersonal relations function, there were three main reasons conveyed by the teachers namely to develop deeper personal relationship with the students, to create secure classroom atmosphere, and to make the class more interesting. In order to create supportive teaching and learning process in the classroom, there should be deep personal relationship between teacher and students so translanguaging appeared as functional bilingual practice to facilitate that relationship. This reason was relevant to Harbord (1992, as cited in Adnan, et al., 2014) who mentions one reason of using $\mathrm{L} 1$ is facilitating teacher-student relationships. Bezzina's (2016) study used the term providing psychological environment to refer to the interpersonal relationships function of translanguaging. The reasons found in this study also promoted Lasagabaster's (2013) study that found L1 was manipulated in translanguaging to feel comfortable in the CLIL class.

\section{CONCLUSION}

The followings are the conclusion of the result of this study. Firstly, the result of the investigation of the functions of teachers' translanguaging found that there were three functions of teachers' translanguaging namely knowledge construction, classroom management and interpersonal relations. Secondly, to refer to the result of teachers' reasons', there were nine reasons of teachers' use of translanguaging which could be categorized into three reasons. They were to facilitate students' understanding, to provide L1 and TL comparison, and to elicit students' response categorized as knowledge construction; to attract students' attention, to be able to manage all students, and to promote discipline categorized as classroom management function; and to develop deeper personal relationship with the students, to create secure classroom atmosphere, and to make the class more interesting could be identified as interpersonal relations.

In connection with the conclusion stated previously, the researcher would like to propose suggestions, which are directed to teachers and any parties interested in the same area of this research. For the teachers, teachers should use translanguaging wisely to avoid the negative impact of the overuse of translanguaging. Therefore the teachers should improve the teaching strategy used so that the use of translanguaging could be reduced. Then, for the other parties which can be the researchers or lecturers who are interested to conduct similar research, it is suggested to solve the weaknesses of this study. The further study can be conducted in longer time, on different place, subject, object, and expand the area of research, method used in collecting and analyzing the data in order to broaden the knowledge about the use of translanguaging in the EFL classroom.

\section{REFERENCES}

Adnan, M. A. M., Mohamad S., Yusoff, M. A., \& Ghazali, Z. (2014). Teachers' attitudes towards the use of first language in Arabic classroom. Journal of Arts, Science \& Commerce, 5(2), 20-28. Retrieved from http://www.researchersworld.com/vol5/i ssue2/Paper_03.pdf.

Baker, C. (2001). Foundations of Bilingual Education and Bilingualism ( $3^{\text {rd }}$ ed.). Clevedon: Multilingual Matters. 
Bezzina, A. M. (2016). Teachers' understanding of the use of language as medium of instruction in 'French as a foreign language' lessons. Malta Review of Educational Research, 10(2), 277-296. Retrieved from http://www.mreronline.org/wpcontent/uploads/2017/01/7-BezzinaTeachers-Understanding-of-the-Use-ofLanguage.pdf.

Bhooth, A., Azman, H. \& Ismail, K. (2014). The role of the $\mathrm{L} 1$ as a scaffolding tool in the EFL reading classroom. Social and Behavioral Science, 76 - 84. Retrieved from

http://www.irjabs.com/files_site/paperlis t/r_918_130715220123.pdf.

Bozorgian, H. \& Fallahpour, S. (2015). Teachers' and students' amount and purpose of L1 use: English as Foreign Language (EFL) Classrooms in Iran. Iranian Journal of Language Teaching Research, 3(2), 67-81. Retrieved from http://files.eric.ed.gov/fulltext /EJ1127239.pdf.

Cahyani, H., Courcy, M. D., \& Barnett, J., (2016). Teachers' code-switching in bilingual classrooms: Exploring Pedagogical and Sociocultural Functions. International Journal of Bilingual Education and Bilingualism, in press, 1-15. Retrieved from http://www.tand fonline.com/doi/full/10.1080/13670050.2 016.1189509 .

Creese, A. \& Blackledge, A. (2010). Translanguaging in the bilingual classroom: A Pedagogy for Learning and Teaching? The Modern Language Journal, 94(1), 103-115. Retrieved from https://www.google.com/url?sa=t\&rct=j $\& q=\&$ esrc $=s \&$ source $=w e b \& c d=1 \& v e d=0 a$ hUKEwjs4J3H_dLbAhVBeysKHbK2DRkQFg goMAA\&url=https\%3A\%2F\%2Fpdfs.sema nticscholar.org\%2F26c0\%2F32139c250cd 9e9a3ed733c5c57a551de89a7.pdf\&usg= AOvVaw1fT_2JF9R_ngdHIS9h1-oo.

Ferguson, G. (2003). Classroom code-switching in post-colonial contexts: Functions, Attitudes and Policies. AlLA review, 16(1), 38-51. Retrieved from https://www.google.com/search?q=Ferg uson $\% 2 \mathrm{C}+$ Classroom+Codeswitching+in+ Post-colonial+

Contexts\%3A+Functions\%2C+Attitudes+a nd+Policies\&ie $=$ utf-8\&oe $=$ utf-

$8 \&$ client=firefox-b.

García, O. (2009). Education, multilingualism and translanguaging in the 21st Century. In T. Skutnabb-Kangas, R. Phillipson, A. K. Mohanty, and M. Panda (Eds.), Social justice through multilingual education (pp. 140-158). Bristol: Multilingual Matters. Retrieved from https://ofeliagarciadotorg.files.wordpress .com/2011/02/education-

multilingualism-translanguaging-21stcentury.pdf.

Harmer, J. (2007). The practice of English language teaching ( $4^{\text {th }}$ ed.). England: Pearson Education Limited.

Hassan, N. \& Ahmed, K. (2015). Exploring translanguaging: A Case Study of a Madrasah in Tower Hamlets. Research in Teacher Education, 5(2), 23-28. Retrieved from http://roar.uel.ac. uk/4763/.

Hidayati, I. N. (2012). Evaluating the role of L1 in teaching receptive skills and grammar in EFL classes. Indonesian Journal of Applied Linguistics. 1(2), 17-32. Retrieved from http://ejournal. upi.edu/index.php/IJAL/article/view/82.

Lasagabaster, D., (2013). The use of the L1 in CLIL classes: The Teachers' Perspective. Latin American Journal of Content and Language Integrated Learning, 6(2), 1-21. Retrieved from 
http://laclil.unisabana.edu.co/index.php/ LACLIL/article/view/3148.

Levine, G. S. (2014). Principles for code choice in the foreign language classroom: A Focus on Grammaring. Language Teaching, 47(3), 332-348. Retrieved from http://journals.

cambridge.org/abstract_S026144481100 0498.

MacSwan, J. (2017). A multilingual perspective on translanguaging. American Educational Research Journal, 54(1), 167201. Retrieved from http://journals. sagepub.com/doi/abs/10.3102/00028312 16683935.

Mahmutoglu, H. and Kicir, Z. (2013). The use of mother tongue in EFL classrooms. EUL Journal of Social Sciences, 4(1), 49-72. Retrieved from http://euljss.eul. edu.tr/euljss/si44.pdf.
Maxwell, J. A., \& Loomis, D. (2002). Mixed method design: An Alternative Approach. In A. Tashakkori \& C. Teddlie (Eds.), Handbook of mixed methods in social and behavioral research (pp. 241-271). Thousand Oaks, CA: Sage. Retrieved from https://www.researchgate.net/file.PostFil eLoader.html ?id $=53146 \mathrm{f} 4 \mathrm{fd} 039 \mathrm{~b} 1 \mathrm{db} 418 \mathrm{~b}$ 45e7\&assetKey=AS\%3A27351512983553 $7 \% 401442222496838$.

Miles, M. B., \& Huberman, A. M. (1984). Qualitative Data Analysis: A Sourcebook of New Methods. California; SAGE publications Inc.

Nambisan, K. A. (2014). Teachers' attitudes towards and uses of translanguaging in English language classrooms in lowa. (Graduate Theses and Dissertations. 14230). Retrieved from http://lib.dr.iastate.edu/etd/ 14230. 